\title{
Antiparasitic effect of Mentha $\times$ villosa hydrolate against monogenean parasites of the Nile tilapia
}

\section{Laura Rafaela da Silva ${ }^{*}$ (D) Julio Cesar Bailler Rodhermel ${ }^{1}$ (D) Jaqueline Inês Alves de Andrade Al $^{1}$ Marina Oliveira Pereira ${ }^{1}$ (i) Amanda Chaaban ${ }^{2}$ (D) Fabiano Cleber Bertoldi $^{3}$ (i) Adolfo Jatobá $^{\text {(i) }}$}

${ }^{1}$ Laboratório de Aquicultura, Instituto Federal Catarinese, Campus Araquari, 89245.000, Araquari, SC, Brasil. E-mail: laurarafa.silva@gmail.com. "Corresponding author.

${ }^{2}$ Instituto Federal Catarinese, Campus Araquari, Araquari, SC, Brasil.

${ }^{3}$ Empresa de Pesquisa Agropecuária e Extensão Rural de Santa Catarina (EPAGRI), Itajaí, SC, Brasil.

${ }^{4}$ Programa de Pós-graduação em Produção e Sanidade Animal, Instituto Federal Catarinense, Campus Araquari, Laboratório de Aquicultura, Araquari, SC, Brasil.

ABSTRACT: This paper o evaluated different concentrations and exposure times of Mentha $\times$ villosa hydrolate for the control of monogenean in Nile tilapia (Oreochromis niloticus). Mentha $\times$ villosa leaves $(150 \mathrm{~g})$ were homogenized and the hydrolate was obtained by hydrodistillation for $4 \mathrm{~h}$ in a Clevenger apparatus. Fifty tilapia were then divided into ten groups (five fish each) and subjected to therapeutic baths for 15 minutes in five different hydrolate concentrations $\left(0,10,20,40\right.$, and $80 \mathrm{ml} . \mathrm{L}^{-1} ; \times 2$ replicates). After a suitable hydrolate concentration was identified, another 50 tilapia were divided into ten groups (five fish each) and subjected to therapeutic baths at the identified hydrolate concentration for five different durations $(0,15,30,45$, and 60 minutes; $\times 2$ replicates $)$. In both steps, the mucus and gills were analyzed to determine parasitological indices. The hydrolate concentration of $20 \mathrm{ml} . \mathrm{L}^{-1}$ showed an efficacy of $59.9 \%$ and the biggest decrease in pathogen prevalence, average abundance, and average infection compared to the control and the lowest concentration (10 ml.L $\left.L^{-1}\right)$. For duration, the best antiparasitic effects were achieved with the 60-minute therapeutic bath, as it resulted in 89.28\% antiparasitic efficacy. Therefore, it was concluded that therapeutic baths of $M . \times$ villosa hydrolate at a concentration of $20 \mathrm{ml} . \mathrm{L}^{-1}$ for 60 minutes have satisfactory antiparasitic effects and could be used to control monogenetic infestations in the gills and mucus of Nile tilapia (O. niloticus).

Key words: herbal medicines, animal health, fish.

Efeito antiparasitário do hidrolato de Mentha $\times$ villosa contra parasitas monogenéticos para Tilápia-do-nilo

RESUMO: Este trabalho teve como objetivo avaliar diferentes concentrações e tempos de exposição do hidrolato de Mentha $\times$ villosa para $o$ controle de monogenéticos em Tilápia-do-nilo (Oreochromis niloticus). Folhas de Mentha $\times$ villosa (150 g) foram homogeneizadas e o hidrolato foi obtido por hidrodestilação por $4 \mathrm{~h}$ em aparelho de Clevenger. Em seguida, 50 tilápias foram divididas em dez grupos (cinco peixes cada) e submetidas a banhos terapêuticos por 15 minutos em cinco diferentes concentrações de hidrolato $\left(0,10,20,40\right.$ e 80 ml. $L^{-1} ; \times 2$ repetições). Após a identificação de uma concentração de hidrolato adequada, outras 50 tilápias foram divididas em dez grupos (cinco peixes cada) e submetidas a banhos terapêuticos na concentração de hidrolato identificada por cinco durações diferentes (0, 15 , 30,45 e 60 minutos; $\times 2$ repetições). Em ambas as etapas, o muco e as guelras foram analisados para determinar os índices parasitológicos. A concentração de hidrolato de 20 ml. $L^{-1}$ apresentou eficácia de 59,9\% e a maior redução na prevalência do patógeno, abundância média e infecção média em relação ao controle e a menor concentração $\left(10 \mathrm{ml} . \mathrm{L}^{-1}\right)$. Para a duração, os melhores efeitos antiparasitários foram alcançados com o banho terapêutico de 60 minutos, uma vez que resultou em 89,28\% de eficácia antiparasitária. Portanto, concluiu-se que banhos terapêuticos de hidrolato de M. × villosa na concentração de $20 \mathrm{ml} . \mathrm{L}^{-1}$ por 60 minutos têm efeitos antiparasitários satisfatórios e podem ser usados para controlar infestações monogenéticas nas brânquias e muco da Tilápia-do-nilo (O. niloticus).

Palavras-chave: fitoterápicos, saúde animal, peixe.

\section{INTRODUCTION}

Parasitic diseases are a common problem in aquaculture. In particular, ectoparasites are of specific note as they can serve as vectors for other pathogens (bacteria, fungi, and viruses); and consequently, help to spread disease and harm animal performance. This can result in financial loss for producers and create public health risks (BASTOS et al., 2016).

Monogenetic helminths are a common ectoparasite of fish grown in intensive systems, as high levels of organic matter contribute to their 
reproduction and development. These helminths have a sclerotic structure, called a haptor, used for attachment to the host, that increases their pathogenicity and causes tissue damage (PAVANELLI et al., 2008). These ectoparasites can cause a loss of function in the gills, impairing respiration and salt exchange with the water, leading to fish mortality (DE MAIO GODOI et al., 2011). In addition, the lesions produced serve as a gateway for systemic bacterial infections (XU et al., 2007).

Several chemicals, such as formalin, sodium chloride, copper sulfate, potassium permanganate, diflubenzuron, and neguvon, are used to control ectoparasites in fish (MARTINS, 2004). However, these products have some disadvantages, including high costs, possible toxicity to fish and humans, possible development of parasitic resistance to active substances, and environmental risks (PAHOR-FIHO et al., 2015). Consequently, there is a need for more sustainable alternatives.

Herbal medicines have been increasingly investigated for their proven efficacy in the treatment and prevention of diseases, especially those caused by parasites (HASHIMOTO et al., 2016; BANDEIRA et al., 2017; RAMAN, 2017), and as sustainable alternatives to chemotherapy. Herbal medicines are mainly taken via oral routes, in dietary supplementation, or in therapeutic baths when added to water (LING et al., 2010; DE ANDRADE et al., 2018).

Among the plants utilized as herbal medicines, mint (Mentha $\times$ villosa) is widely used in phytotherapy for its anti-inflammatory, antihepatotoxic, anthelmintic, and immunostimulant (ARRUDA et al., 2006) properties. Studies have shown that $M . \times$ villosa hydrolate exerted an ovicidal effect on bovine gastrointestinal nematodes in an in vitro test (NASCIMENTO et al., 2009). Other studies have demonstrated the in vitro biological effects of $M . \times$ villosa essential oils on $S$. mansoni worms, which resulted in decreased motility and, with higher concentrations, mortality (MATOS-ROCHA et al., 2013).

However, no previous studies have elucidated the medicinal use of hydrolate, a byproduct of the extraction of essential oils from plants, in therapeutic baths for the treatment of parasitized fish. Despite having several pharmacological effects, hydrolates have typically been discarded after the extraction of oils as having no commercial purpose. Therefore, this study evaluated different concentrations and exposure times of Mentha $\times$ villosa hydrolate for the control of monogeneans in Nile tilapia (Oreochromis niloticus).

\section{MATERIALS AND METHODS}

\section{Plant material}

The botanical species used in this research were grown in the Medical Plants Unit at the Instituto Federal Catarinense, campus Araquari, located at $26^{\circ}$ $23^{\prime} 33.6691$ ' S and $48^{\circ} 44^{\prime} 18.3336 " \mathrm{~W}$, at $10.6 \mathrm{~m}$ above sea level, in the city of Araquari, Santa Catarina State, southern Brazil. Plants were cultivated in an agroecological system without the application of agrochemical products. Mentha $\times$ villosa leaves were collected from approximately 50 individuals from March to June 2018 (Brazilian autumn). A voucher specimen of the botanical material was deposited at the Botanical Museum Herbarium, located in the Botanic Garden of Curitiba, PR, with the number 358966.

\section{Obtaining the hydrolate}

M. $\times$ villosa hydrolate, a by-product of essential oil distillation, was achieved by hydrodistillation (VENSKUTONIS, 1997) using the Clevenger apparatus, adapted to a $2000 \mathrm{~mL}$ flask in which the mint leaves were placed together with $1000 \mathrm{~mL}$ of distilled water according to CORADI et al. (2018). Fresh leaves of $M . \times$ villosa $(150 \mathrm{~g})$ were used for each distillation. The extraction time was $90 \mathrm{~min}$, starting from the time of boiling. After the hydrolate (mixture of oil and water) was obtained, separation of the essential oil was initiated using the organic solvent pentane $(3 \times 50 \mathrm{~mL})$ in a separating funnel. After a few minutes of resting, the solution was filtered and concentrated on a rotary evaporator at $40{ }^{\circ} \mathrm{C}$, until the solvent volume was significantly reduced.

The hydrolate obtained from the hydrodistillation of the leaves of Mentha $x$ villosa was treated with chromatographic grade hexane to perform a liquid-liquid extraction with approximately $2 \mathrm{ml}$ of hexane for $100 \mathrm{ml}$ of hydrolate in a separating funnel. A fraction of $500 \mu \mathrm{L}$ of the organic phase was collected to perform a chemical analysis of the volatile components of the hydrolate of Mentha $\times$ villosa by gas chromatography with a mass spectrometry detector (GCMS, Shimadzu, model GCMS - QP2010). A ZB-5MS capillary column, 30 $\mathrm{m} \times 0.25 \mathrm{~mm} \times 0.25 \mu \mathrm{m}$ film, was used. The injector temperature was $250{ }^{\circ} \mathrm{C}$ and the helium carrier gas flow was $1.0 \mathrm{~mL} \cdot \mathrm{min}^{-1}$. The chromatograph oven was optimized with an initial temperature of $60^{\circ} \mathrm{C}$ for 4 minutes until reaching $210^{\circ} \mathrm{C}$, then remaining for 6 minutes, and the total chromatographic run lasted 35 minutes. A fraction extracted from the hydrolate was diluted 2 times in chromatographic grade hexane,;and 
subsequently, $1 \mu \mathrm{L}$ was injected into the GCMS. The quantification of each component was determined by normalizing the areas (\%) of the peaks in the total ion chromatogram (TIC), with the total area, which was the sum of all areas of the eluted peaks $(100 \%)$.

Retention rates were calculated according to VAN DEN DOLL \& KRATZ (1963) from n-alkane standards (C7-C30), with the same chromatographic conditions as the samples of the essential oils. The identification by GCMS was based on the comparison of the mass spectra with NIST-05 data libraries, and by comparing the retention rates calculated with those reported in the literature (databases - WebNIST, GMD).

\section{Fishpond}

The Nile tilapia (O. niloticus) used in this research were reared in a pond $\left(32 \mathrm{~m}^{3}, 11.6 \mathrm{~m} \times 5.0\right.$ $\mathrm{m} \times 0.5 \mathrm{~m})$ covered with a geomembrane $(8 \mathrm{~mm})$. The pond had a daily water renewal rate of $10 \%$. Fish were fed four times a day with a commercial diet (Guabi, 32\% crude protein), and the stocking density was approximately 10 fish.m ${ }^{-3}$.

\section{Definition of concentration}

From this pond, fifty Nile tilapias (172.81 $\pm 31.9 \mathrm{~g}$ and $20.5 \pm 1.5 \mathrm{~cm}$ ) were divided into ten groups of five fish each. All were submitted to therapeutic baths using five different $M . \times$ villosa hydrolate concentrations (control/ $0,10,20,40$, and $\left.80 \mathrm{ml} . \mathrm{L}^{-1}\right)$. Fish were kept in buckets with 5 liters of water from the rearing pond, each containing five fish (stocking density 1 fish. $\mathrm{L}^{-1}$ ), and each bucket was equipped with a constant aeration system (pumped air). All baths were performed for 15 minutes.

\section{Exposure/action time}

After defining the most efficient concentration of hydrolate, another fifty Nile tilapias $(176.81 \pm 4.7 \mathrm{~g}$ and $20.9 \pm 0.35 \mathrm{~cm})$ were collected from the same fish tank as indicated in the previous section (definition of concentration). All were submitted to therapeutic baths, using five different exposure times (control/0, 15, 30, 45 and 60 minutes) to the Mentha $\times$ villosa hydrolate, at the concentration identified as suitable in the previous section (Definition of concentration). Fish were kept in buckets with 5 liters of water from the rearing pond, except for the control treatment, for which parasitological analysis was performed immediately after collection. Each bucket contained five fish (stocking density 1 fish. $\mathrm{L}^{-1}$ ) and was equipped with a constant aeration system (pumped air).

\section{Parasitological analysis}

After therapeutic baths, the Nile tilapia were anesthetized with eugenol $\left(50 \mathrm{mg} \mathrm{L}^{-1}\right)$, the mucus was removed by scraping the entire length of the skin, and then the tilapias were euthanized via spinal cord section. The gills were removed individually and analyzed with a stereomicroscope (ZEISS Stemi DV4) to determine the levels of infestation (JERÔNIMO et al. 2011). Prevalence of parasitological descriptors (P), mean infection (MI), and mean abundance (MA) were determined as described previously by BUSH et al. (1997). According to DOTTA et al. (2015), effectiveness was determined as $\mathrm{E}=\mathrm{MNPCG}$ MNPTG $\times 100 /$ MNPCG, where E is effectiveness, MNPCG is the average number of parasites in the control group, and MNPGT is the average number of parasites in the treated group.

\section{Statistical analysis}

Data were previously submitted to Bartlett's analysis to verify their homogeneity of variance. Second order polynomial regressions were performed to evaluate concentration and time. All tests were performed using SPSS Statistics software, version 25 (ZAR, 2010).

\section{RESULTS AND DISCUSSION}

Plants of the genus Mentha are valuable for industry, as their extracts and derived essential oils exert notable effects against a broad spectrum of bacteria, fungi, and yeasts, when tested in vitro (SALEHI et al., 2018), and their use has also been observed in aquaculture (HASHIMOTO et al., 2016). Carvone was the most abundant compound in the Menta $\times$ villosa hydrolate, representing almost $90 \%$ of the sample profile (Table 1), the same compound also was a predominant chemical (89.7\%) in the crude volatile oil of Sphaeranthus amaranthoides (MURFADUNNISA et al., 2014). This compound has previously been investigated as a feed additive for veterinary and medicinal use (EFSA, 2014), and may have a role in aquaculture as an anesthetic (MORCIA et al., 2016).

Several studies have confirmed the antiparasitic effects of essential oils for fish (DA COSTA, 2017; SOARES, et al., 2016), but few have used hydrolate as a phototherapeutic. For cattle, NASCIMENTO et al. (2009) demonstrated that $M . \times$ villosa hydrolate has an ovicidal effect on bovine gastrointestinal nematodes, and JULIO et al. (2017) observed nematocidal activity with hydrolate treatments (60\% and $20 \%$ concentrations) of Artemisia absinthium against Meloidogyne javanica. 
Table 1 - Volatile profile of Mentha $x$ villosa hydrolate.

\begin{tabular}{lccc}
\hline Components & RIc & RIl & Percentage $(\%)$ \\
\hline 1.8 -cineol & 1034 & 1033 & 0.69 \\
trans-Sabinene hydrate & 1070 & 1070 & 1.06 \\
Terpinen-4-ol & 1183 & 1181 & 1.93 \\
Dihydrocarveol & 1200 & 1202 & 1.80 \\
trans-Carveol & 1221 & 1220 & 2.41 \\
Carvone & 1248 & 1246 & 89.73 \\
ar-tumerone & 1666 & 1669 & 2.03 \\
Total identified & - & - & 99.65 \\
\hline
\end{tabular}

RIc $=$ Retention index calculated, RIl $=$ Retention index of literature, $\%=$ percentage of the component in the volatile fraction of the hydrolate.

The main compound of the $M . \times$ villosa hydrolate was Carvone.Previousreportshavedemonstrated the capacity of carvone as a potential synthetic pesticide for agriculture and veterinary applications (SHAH \& HORSLER, 2012), and have recommended it as an environmentally friendly parasiticide and insecticide (FRANZIOS et al., 1997). In addition, Carvone can be used synergistically with antiparasitic and pestcontrol compositions (ENAN, 2011, 2014).

The recent discovery of hydrolates as potential therapeutic products means that there is a need to assess their ideal concentrations and application durations, given the inefficiency of low doses and because overdosing creates risks for the health of animals, as demonstrated in medical studies. The U.S. Food and Drug Administration (FDA) from 1993 to 1998 detected 5,307 cases of medical error with medications; among them, $40.9 \%$ of cases involved inadequate dosage and subsequent mortality (COHEN, et al., 2000).

The tilapia used in these experiments exhibited infestation with monogenoid parasites (Monogenea sp.). UEDA et al. (2013) reported that the monogenoid group was the most prevalent in freshwater fish in Brazil. Parasites of this class are potential disease agents and have previously been described in other fish species (DUTTA et al., 2015; JERÔNIMO et al., 2011).

In this research, the parasitological counts performed in the first experiment demonstrated that a concentration of $20 \mathrm{ml} . \mathrm{L}^{-1}$ of $\mathrm{M} . \times$ villosa hydrolate obtained the same results as the highest concentrations, reducing the prevalence of monogenous mucus by $40 \%$ (Figure 1A). MA and MI had lower counts of monogeneans in their mucus and gills at the concentration of $20 \mathrm{ml} . \mathrm{L}^{-1}$ compared to the lowest concentration tested $\left(10 \mathrm{ml} . \mathrm{L}^{-1}\right)$ and the control treatment. In addition, the concentration of $20 \mathrm{ml} . \mathrm{L}^{-1}$ demonstrated antiparasitic efficacies of $58.33 \%$ and $59.54 \%$ against the monogeneans in the mucus and gills of $O$. niloticus, respectively. This result was equal to that with highest concentrations tested $\left(40 \mathrm{ml} . \mathrm{L}^{-1}\right.$ and $\left.80 \mathrm{ml} . \mathrm{L}^{-1}\right)$ but better than those with the $10 \mathrm{ml} . \mathrm{L}^{-1}$ (Figure 2). This hydrolate showed better efficacy than the essential oil of Mentha $\times$ piperita, in which $40 \mathrm{mg} . \mathrm{L}^{-1}$ was necessary for 41.63 $\%$ efficacy against monogeneans in Nile tilapia $(O$. niloticus) (HASHIMOTO et al., 2016). The 20, 40, and $80 \mathrm{ml} . \mathrm{L}^{-1}$ proved to be more effective than the 10 $\mathrm{ml} . \mathrm{L}^{-1}$. Therefore, the lowest concentration, $20 \mathrm{ml} . \mathrm{L}^{-1}$, was used in the second experiment to reduce the cost but optimize its use.

The second experiment demonstrated that increasing the immersion bath time with $M$. × villosa hydrolate gradually decreased the prevalence of monogenous mucus (Figure 3A), as well as monogenous MA and $\mathrm{MI}$ in the gills and mucus of the tilapia (Figures 3B and 3C).

The 60-minute therapeutic bath showed higher antiparasitic efficacy at $89.29 \%$ and $80.19 \%$ for mucus and gills, respectively (Figure 4). According to the Ministry of Agriculture, Livestock and Supply (Ministério da Agricultura, Pecuária e Abastecimento in Portuguese), Ordinance $N^{\circ} 48$ of 12/12/1997, the registration of antiparasitic products for domestic mammals requires an efficiency above $90 \%$. However, for fish and/or aquatic organisms, no legislation has defined the degree of medicinal efficacy. According to ONAKA et al. (2018), this may hinder the evaluation of new drugs or treatments, since the goal of treatment is the significant control of parasites, not necessarily their elimination above $90 \%$. 


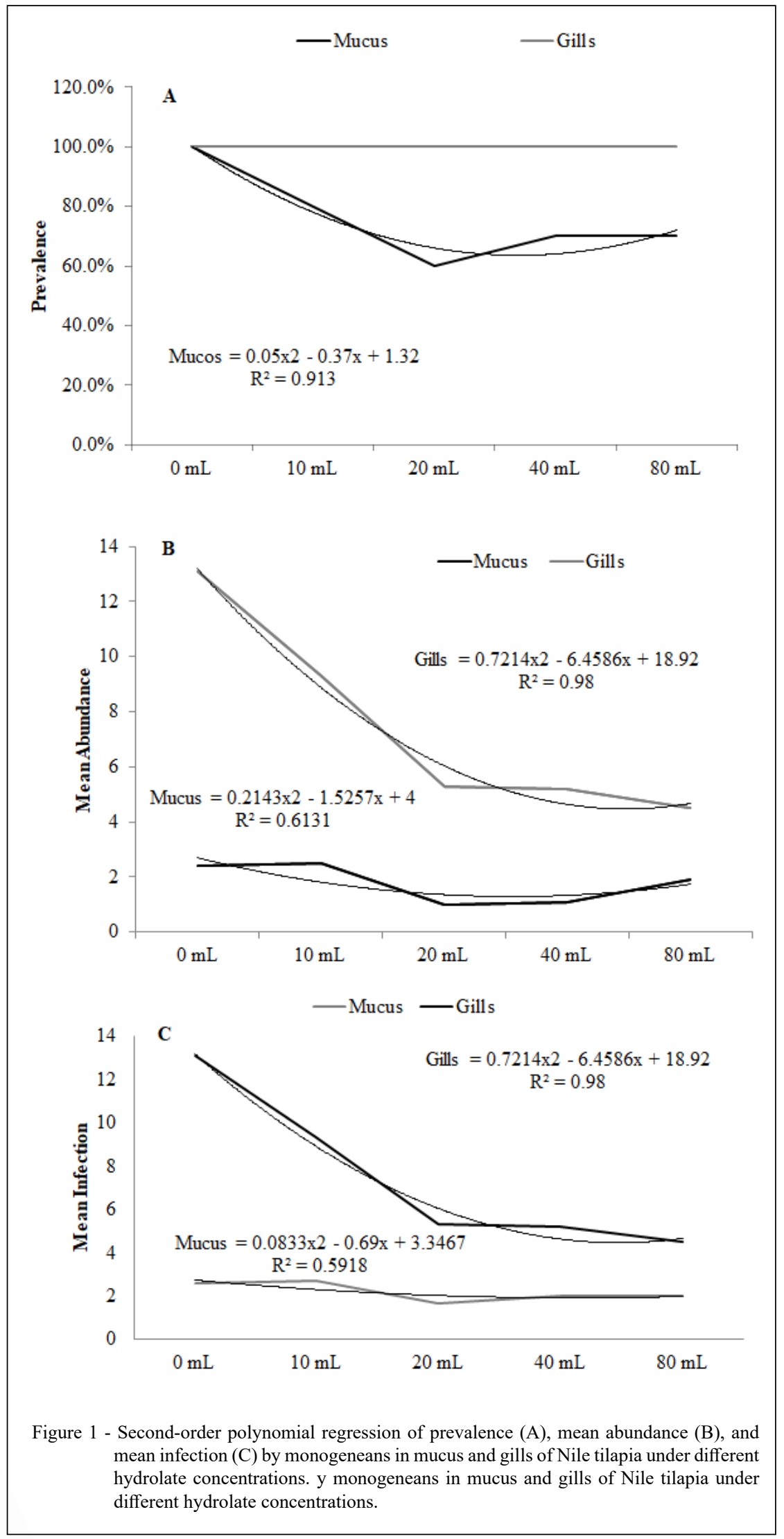

Ciência Rural, v.51, n.10, 2021. 


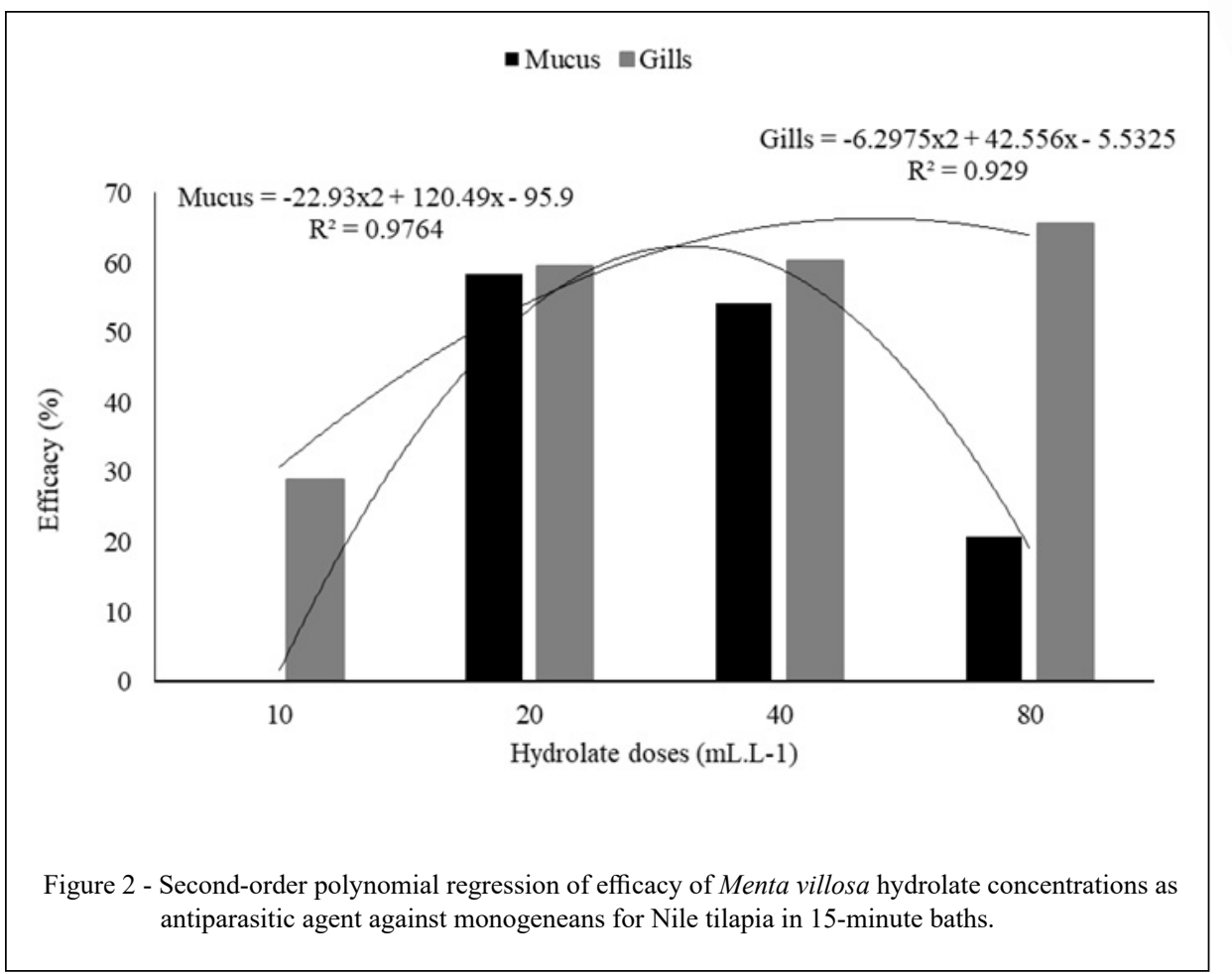

Figure 4 shows an increase in the effectiveness of hydrolate in the gills in direct proportion to the duration of the therapeutic bath. The 60 -minute bath was $17.13 \%$ and $28.6 \%$ more efficient than the 45- and 30-minute baths, respectively. Similar results reported by CORRAL (2014) who confirmed that Piper aduncum extract at a concentration of 40 g. $\mathrm{L}^{-1}$ in 60-minute baths for tambaqui (Colossoma macropomum) obtained an average of 4.7 live and 92.2 dead monogenoids.

The increase in therapeutic bath time improved the effectiveness of the treatment for the gills, whereas the efficacy of $M . \times$ villosa hydrolate in mucus suggests a 30-minute therapeutic bath at a concentration of $20 \mathrm{ml}^{-\mathrm{L}^{-1}}$. We found that these results were equal to those for a 1-hour bath. This can be explained by the exposure of the parasites to the hydrolate since mucus is the layer covering fish integument and the most external part of the animal.
The results of this study showed the antiparasitic effect of $M . \times$ villosa hydrolate against monogeneans for Nile Tilapia (O. niloticus). For 15-min therapeutic baths of $M . \times$ villosa hydrolate, concentrations of 20 and $80 \mathrm{ml} . \mathrm{L}^{-1}$ were shown to have the same antiparasitic effect. It is recommended; however, that the lowest concentration be used to reduce costs and optimize use of the by-product. As a general protocol, one-hour therapeutic baths of $M . \times$ villosa hydrolate at $20 \mathrm{ml} . \mathrm{L}^{-1}$ are indicated to control monogenetic infestations in the gills and mucus of Nile tilapia (O. niloticus). However, the profile of the hydrolate composition can change due to several variables such as raw material, extraction method and plant tissues used for extraction, and harvesting season. To repeat the results reported in this investigation, the hydrolate extract must have a similar chemical profile to that used in this experiment. An alternative to investigate further is the use of synthetic carvone with the same concentration. 


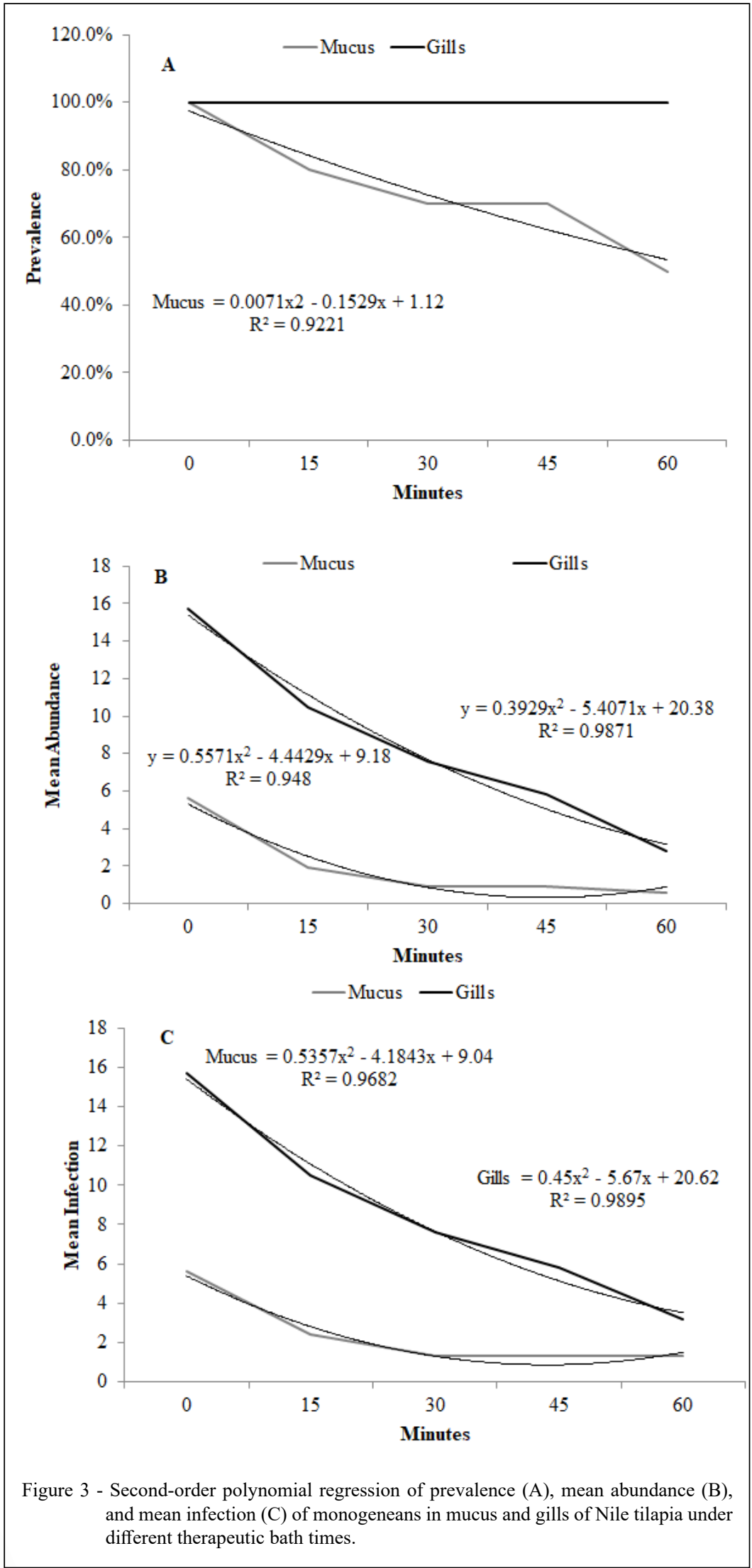

Ciência Rural, v.51, n.10, 2021. 


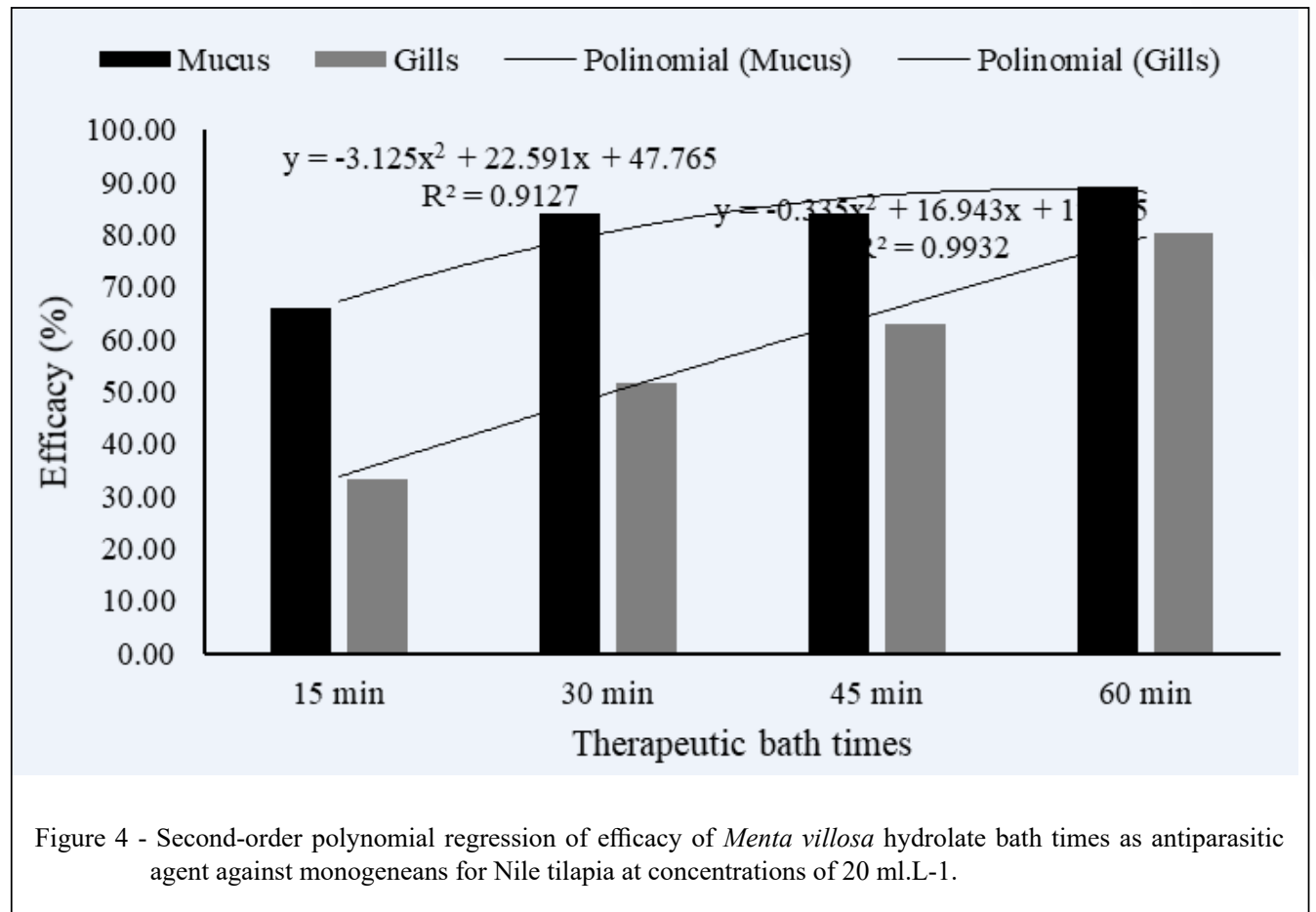

\section{ACKNOWLEDGEMENTS}

We thank the Conselho Nacional de Desenvolvimento Científico e Tecnológico (CNPq) for offering scholarships; PIBICCNPq (No. 21-2017) and PIBIC-EM IFC/CNPq (No. 20-2017) for the development of the project; and GUABI for financing the diets used. And was financed in part by the Coordenação de Aperfeiçoamento de Pessoal de Nível Superior (CAPES), Brasil Finance code 001.

\section{BIOETHICS AND BIOSSECURITY COMMITTEE APPROVAL}

This work was carried out at the Laboratorio de Aquicultura, Catarinense Federal Institute, Araquari Campus. This research was approved by the Animal Ethics Committee (Protocol No. 192/2017).

\section{DECLARATION OF CONFLICT OF INTEREST}

The authors declare no conflict of interest. The founding sponsors had no role in the design of the study; in the collection, analyses, or interpretation of data; in the writing of the manuscript, and in the decision to publish the results.

\section{AUTHORS' CONTRIBUTIONS}

Laura Rafaela da Silva, Julio Cesar Bailler Rodhermel and Adolfo Jatobá designed and carried out the experiments,
Jaqueline Inês Alves de Andrade and Marina Oliveira Pereira conducted the laboratory analyzes. Amanda Chaaban and Fabiano Cleber performed the analysis of the hydrolate of Mentha $\mathrm{x}$ villosa. Laura Rafaela da Silva and Adolfo Jatobá performed the statistical analysis of the experimental data. Laura Rafaela da Silva prepared the draft of the manuscript. All authors critically reviewed the manuscript and approved the final version.

\section{REFERENCES}

ARRUDA, T. et al. Preliminary study of the antimicrobial activity of Mentha $x$ villosa Hudson essential oil, rotundifolone and its analogues. Revista Brasileira de Farmacognosia, v.16, n.3, p.307-311, 2006. Available from: <http://www.scielo. br/scielo.php?pid=S0102-695X2006000300005\&script $=$ sci arttext>. Accessed: Nov. 24, 2019. doi: 10.1590/S0102$695 \times 2006000300005$.

BANDEIRA, G. et al. Potential uses of Ocimum gratissimum and Hesperozygis ringens essential oils in aquaculture. Industrial Crops and Products, v.97, p.484-491, 2017. Available from: $<$ https://doi.org/10.1016/j.indcrop.2016.12.040>. Accessed: Nov. 24, 2019. doi: 10.1016/j.indcrop.2016.12.040.

BASTOS, G.e tal. Current status of parasitic ciliates Chilodonella spp. (Phyllopharyngea: Chilodonellidae) in freshwater fish aquaculture. Journal of Fish Diseases, 2016. Available from: $<$ https://doi.org/10.1111/jfd.12523>. Accessed: Nov. 24, 2019. doi: $10.1111 /$ jfd. 12523 .

BRASIL. Ministério da Agricultura, Pecuária e Abastecimento. Instrução Normativa $n^{\circ} 48$ de 12 de dezembro de 2017. Aprova 
os mecanismos de controle e informação da qualidade orgânica e aprova os formulários oficiais do Ministério da Agricultura, Pecuária e Abastecimento. Brasília, DF, $\mathrm{n}^{\circ}$ 101, 18 dezembro, 2017. Seção: 1, Página: 41-42.

COHEN, M. R.;et al., Preventing Medications Errors in Cancer Chemotherapy. AM. J. Health Syst. Pharm., Bethesda, v.53 p.73746, 2000. Available from: <https://doi.org/10.1093/ajhp/53.7.737>. Accessed: Nov. 24, 2019. doi: 10.1093/ajhp/53.7.737.

CORRAL, A. C. T. et al. Control of Hysterothylacium sp.(Nematoda: Anisakidae) in juvenile pirarucu (Arapaima gigas) by the oral application of essential oil of Piper aduncum. Aquaculture, v.494, p.37-44, 2018.

CORRAL, A. C. T. et al. Control of Hysterothylacium sp.(Nematoda: Anisakidae) in juvenile pirarucu (Arapaima gigas) by the oral application of essential oil of Piper aduncum. Aquaculture, v.494, p.37-44, 2018. Available from: <https://doi. org/10.1016/j.aquaculture.2018.04.062>. Accessed: Dec. 02, 2019. doi: 10.1016/j.aquaculture.2018.04.062

DA COSTA, J. C. et al. Copaifera duckei oleoresin as a novel alternative for treatment of monogenean infections in pacu Piaractus mesopotamicus. Aquaculture, v.471, p.72-79, 2017. Available from: $\quad<$ https://doi.org/10.1016/j.aquaculture.2016.11.041> Accessed: Nov. 24, 2019. doi: 10.1016/j.aquaculture.2016.11.041.

DE ANDRADE, J. I. A. et al. Hematology and biochemistry of Colossoma macropomum co-infected with Aeromonas hydrophila and monogenean Anacanthorus spathulatus after treatment with seed extract of Bixa orellana. Aquaculture, v.495, p.452-457, 2018. Available from: <https://doi.org/10.1016/j. aquaculture.2018.06.026>. Accessed: Nov. 24, 2019. doi: 10.1016/j.aquaculture.2018.06.026.

DE MAIO GODOI, M. M. I. et al. Parasite-host relationship between the tambaqui (Colossoma macropomum Cuvier 1818) and its parasites, collected from fish farms in the City of Rolim de Moura, State of Rondonia, Western Amazon, Brazil. Acta Amazonica, v.42, n.4, 2011. Available from: < http://acta.inpa.gov br/fasciculos/42-4/PDF/v42n4a09.pdf>. Accessed: Nov. 24, 2019. doi: 10.1590/S0044-59672012000400009.

DOTTA, G., et al. Effect of dietary supplementation with propolis and Aloe barbadensis extracts on hematological parameters and parasitism in Nile tilapia. Revista Brasileira de Parasitologia Veterinária, v.24, n.1, p.66-71, 2015. Available from: <http:// dx.doi.org/10.1590/S1984-29612015004>. Accessed: Nov. 24, 2019. doi: 10.1590/S1984-29612015004.

EFSA SCIENTIFIC COMMITTEE. Scientific Opinion on the safety assessment of carvone, considering all sources of exposure. EFSA Journal, v.12, n.7, p.3806, 2014. Available from: <https:// efsa.onlinelibrary.wiley.com/doi/abs/10.2903/j.efsa.2014.3806>. Accessed: Jul. 20, 2020. doi: 10.2903/j.efsa.2014.3806.

$\begin{array}{llrr}\text { ENAN, } & \text { E. } & \text { Synergistic } & \text { antiparasitic } \\ \text { compositions } & & \text { and } & \text { screening }\end{array}$ US2011008471, January 13, 2011. Available from: < https://patents. google.com/patent/US20110008471A1/en>. Accessed: Jul. 20, 2020.

ENAN, E. Synergistic pest-control compositions. US 20100303940 A1, May 27, 2014. Available from: <https://patents.google.com/patent/ US8734869B2/en>. Accessed: Jul. 20, 2020.

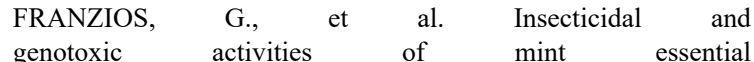
oils. Journal of Agricultural and Food Chemistry, v.45, n.7, p.2690-2694, 1997. Available from: <https://pubs.acs.org/doi/ full/10.1021/jf960685f>. Accessed: Jul. 20, 2020. doi: 10.1021/ jf960685f.

HASHIMOTO, G. S. et al. Essential oils of Lippia sidoides and Mentha piperita against monogenean parasites and their influence on the hematology of Nile tilapia. Aquaculture, v.450, p.182-186, 2016. Available from: <https://doi.org/10.1016/j. aquaculture.2015.07.029>. Accessed: Nov. 24, 2019. doi: 10.1016/j.aquaculture.2015.07.029.

JERÔNIMO, G. T. et al. Seasonal influence on the hematological parameters in cultured Nile tilapia from southern Brazil. Brazilian Journal of Biology, v.71, n.3, p.719-725, 2011. Available from: $<$ http://dx.doi.org/10.1590/S1519-69842011000400017>. Accessed:Nov.24,2019.doi: 10.1590/S1519-69842011000400017.

JULIO, L. F. et al. Nematicidal activity of the hydrolate byproduct from the semi industrial vapor pressure extraction of domesticated Artemisia absinthium against Meloidogyne javanica. Crop Protection, v.94, p.33-37, 2017. Available from: <https://doi. org/10.1016/j.cropro.2016.12.002>. Accessed: Nov. 24, 2019. doi: 10.1016/j.cropro.2016.12.002.

LING, F. et al. Prevention of Ichthyophthirius multifiliis infestation in goldfish (Carassius auratus) by potassium ferrate (VI) treatment. Veterinary parasitology, v.168, n.3, p.212-216, 2010. Available from: <https://doi.org/10.1016/j.vetpar.2009.11.009>. Accessed: Nov. 24, 2019. doi: 10.1016/j.vetpar.2009.11.009.

MARTINS, M. L. Cuidados básicos e alternativas no tratamento de enfermidades de peixes na aqüicultura brasileira. Sanidade de Organismos aquáticos, p.355-368, 2004.

MATOS-ROCHA, T. J. et al. In vitro evaluation of schistosomicidal activity of essential oil of Mentha $x$ villosa and some of its chemical constituents in adult worms of Schistosoma mansoni. Planta medica, v.79, n.14, p.1307-1312, 2013.

MORCIA, C. et al. Carvone (Mentha spicata L.) oils. In: Essential oils in food preservation, flavor and safety. Academic Press, 2016. p.309-316. Available from: <https://www.sciencedirect. com/science/article/pii/B9780124166417000353>. Accessed: Jul. 20, 2020. doi: 10.1016/B978-0-12-416641-7.00035-3.

MURFADUNNISA, S. et al. Larvicidal and enzyme inhibition of essential oil from Spheranthus amaranthroids (Burm.) against lepidopteran pest Spodoptera litura (Fab.) and their impact on non-target earthworms. Biocatalysis and agricultural biotechnology, v.21, p.101324, 2019. Available from: <https://www.sciencedirect.com/science/article/abs/pii/ S1878818119310965?via\%3Dihub>. Accessed: Jul. 20, 2020. doi: 1 10.1016/j.bcab.2019.101324.

NASCIMENTO, É M, et al. Efeito anti-helmíntico do hidrolato de Mentha villosa Huds. (Lamiaceae) em nematóides gastrintestinais de bovinos. Ciência Rural, v.39, n.3, 2009. Available from: < http:// dx.doi.org/10.1590/S0103-84782009005000017>. Accessed: Nov. 24, 2019. doi: 10.1590/S0103-84782009005000017.

ONAKA, E et al., Eficácia do albendazol e praziquantel no controle de Anacanthorus penilabiatus (monogenea: dactylogyridae), parasito de pacu Piaractus mesopotamicus (osteichthyes: 
characidae). I. Banhos terapêuticos. Boletim do Instituto de Pesca, v.29, n.2, p.101-107, 2018. Available from: $<$ https://www. pesca.sp.gov.br/boletim/index.php/bip/article/view/Onaka $>$. Accessed: Nov. 24, 2019.

PAVANELli, G. C., EIRAS, J. C., TAKEMOTO, R. M., 2008. Doenças de Peixes. In: Profilaxia, Diagnóstico e Tratamento, (3th edn). Universidade Estadual de, Maringá, pp.305.

RAMAN, R. P.. Applicability, Feasibility and Efficacy of Phytotherapy in Aquatic Animal Health Management. American Journal of Plant Sciences, v.8, n.02, p.257, 2017. Available from: $<$ https://m.scirp.org/papers/73693>. Accessed: Nov. 24, 2019. doi: 10.4236 / ajps. 2017.82019 .

SALEHI, B. et al. Plants of genus Mentha: From farm to food factory. Plants, v.7, n.3, p.70, 2018. Available from: <https:// www.mdpi.com/2223-7747/7/3/70>. Accessed: Jul. 20, 2020. doi: $10.3390 /$ plants 7030070 .

SHAH, S. A., HORSLER, C. W. Insecticidal composition. US20090263511A1, March 20, 2012. Available from: <https://patents.google.com/ patent/US8137715B2/en>. Accessed: Jul. 20, 2020.

SOARES, B. V., et al. Antiparasitic, physiological and histological effects of the essential oil of Lippia origanoides (Verbenaceae) in native freshwater fish Colossoma macropomum. Aquaculture, 2017, 469: 72-78. Available from: <https://doi.org/10.1016/j. aquaculture.2016.12.001>. Accessed: Nov. 24, 2019. doi: 10.1016/j.aquaculture.2016.12.001.

UEDA B. H., et al., Parasites of the freshwater fish trade in Brazil: science metric study. Pesquisa Veterinária Brasileira, v.33, ISSN: 2446-6778-REINPEC-Páginas 145 de 288 n. 7, p. 851-854. 2013. Available from: $<$ https://www.scielo.br/scielo.php?pid=S0100736X2013000700004\&script $=$ sci_arttext $>$. Accessed: Jul. 20, 2020. doi: 10.1590/S0100-736X2013000700004.

VAN DEN DOOL, H.; KRATZ, P. Dec. A generalization of the retention index system including linear temperature programmed gas - liquid partition chromatography. Journal of Chromatography A, v.11, p.463-471, 1963. Available from: $<$ https://worldveg.tind.io/record/1766/>. Accessed: Jul. 20, 2020.

VENSKUTONIS, P. R. et al., Marija. composition of the essential oil of Lavender (Lavandula angustifolia Mill.) from Lithuania. Journal of essential oil research, 1997, 9.1: 107-110. Available from: $<$ https://doi.org/10.1080/10412905.1997.9700727>. Accessed: Nov. 24, 2019. doi: 10.1080/10412905.1997.9700727.

XU, D. H.; et al.,Evaluation of the link between gyrodactylosis and streptococcosis of Nile tilapia, Oreochromis niloticus (L.). Journal of Fish Diseases, v.30, n.4, p.233-238, 2007. Available from: $<$ https://doi.org/10.1111/j.1365-2761.2007.00806.x>. Accessed: Nov. 24, 2019. doi: 10.1111/j.1365-2761.2007.00806.x.

ZAR, JERROLD H. Biostatistical Analysis, 5th. 2010. 